\title{
PERAN MEDIA MASSA DALAM MENINGKATKAN SELF-AWARENESS MASYARAKAT TERHADAP PENTINGNYA VAKSINASI COVID-19 DI KABUPATEN SIDOARJO
}

\author{
Hana Nabilah Santoso, ${ }^{1}$ Nikmah Hadiati Salisah ${ }^{2}$ \\ ${ }^{1,2}$ Universitas Islam Negeri SunanAmpel Surabaya \\ ${ }^{1}$ Hananabilahs99@gmail.com, ${ }^{2}$ Nikmah_hs@yahoo.co.id
}

\begin{tabular}{l}
\hline Article Info \\
\hline Article history: \\
Received 1 Juli 2021 \\
Accepted 25 Agustus 2021 \\
Published 1 Oktober 2021
\end{tabular}

Keyword:

Peran Media Massa, Self-Awareness, Vaksinasi Covid-19

\begin{abstract}
Some people in Sidorajo Regency are still unsure about the Covid-19 vaccination. This is due to the widespread information on vaccination programs that confuses the public, people feel doubtful and do not care about the vaccination program. Therefore, the Covid-19 vaccination program in the Sidoarjo Regency has not yet reached the specified target. This study will explain how the role of the mass media in increasing the self-awareness of the people of Sidoarjo on the importance of the Covid-19 vaccination. The research method used is qualitative. The results showed that the role of the mass media are: 1) As a window of information, mass media providing a lot of knowledge to the people of Sidoarjo through various media partners. 2) As a reflection of reality, mass media partners of Sidoarjo Regency Government present the latest information related to Covid-19 information in the field. 3) As a filter, mass media capture hoax information circulating in Sidoarjo. 4) As a guide, the mass media direct the correct information if the public is confused. 5) As a forum, Sidoarjo's media partner become a forum for the community to provide feedback on the information received. 6) As a communication partner, mass media of Sidoarjo partners are a place to submit statements or questions.

Sebagian masyarakat Kabupaten Sidorajo masih ragu tentang vaksinasi covid-19. Hal tersebut dikarenakan maraknya informasi program vaksinasi yang membingunkan masyarakat, masyarakat merasa ragu dan acuh terhadap program vaksinasi. Sehingga program vaksinasi Covid-19 di wilayah Kabupaten Sidoarjo belum mencapai target yang ditentukan. Penelitian ini akan menjelaskan bagaimana peran media massa dalam meningkatkan self-awareness masyarakat Sidoarjo terhadap pentingnya vaksinasi Covid-19. Metode penelitian yang digunakan adalah kualitatif. Hasil penelitian menunjukkan bahwa peran media massa 1) Sebagai jendela informasi, memberikan banyak pengetahuan kepada masyarakat Sidoarjo melalui berbagai mitra media. 2) Sebagai refleksi realitas, media massa mitra Pemkab Sidoarjo menyajikan informasi terkini terkait informasi Covid-19 yang ada dilapangan. 3) Sebagai filter, media massa menjaring informasi-informasi hoax yang beredar di Sidoarjo. 4) Sebagai guide, media massa mengarahkan pada informasi yang benar jika masyarakat mengalami kebingungan. 5) Sebagai forum, mitra media Sidoarjo menjadi wadah bagi masyarakat untuk memberikan umpan balik atas informasi yang diterima. 6) Sebagai partner komunikasi, media massa mitra Sidoarjo menjadi tempat untuk menyampaikan pernyataan ataupun pertanyaan.
\end{abstract}

Copyright (C) 2021 Jurnal Ilmu Komunikasi. All rights reserved.

Editorial Office:

Program Studi Ilmu Komunikasi, Fakultas Dakwah dan Komunikasi, UIN Sunan Ampel Surabaya.

Jl. Ahmad Yani 117 Surabaya, Jawa Timur, Indonesia.

Email: jurnalilkom@uinsby.ac.id 


\section{Pendahuluan}

Virus Covid-19 atau Corona Virus Disease 2019 yang berasal dari Wuhan, China telah diumumkan oleh World Health Organization (WHO) sebagai pandemi pada awal tahun 2020. Pandemi Covid-19 menjadi bencana yang telah merenggut jutaan nyawa manusia sejak awal kemunculannya pada akhir tahun 2019. Kehadirannya membawa banyak kerugian bagi umat manusia, tanpa terbayangkan sebelumnya. Dampak masif dari virus ini membawa pada ketidakpastiaan yang menyebabkan krisis kesehatan dan ekonomi. Banyak upaya yang dilakukan diberbagai negara untuk menekan penyebaran Covid-19, tidak terkecuali di Indonesia.

Pemerintah pusat memberlakukan berbagai kebijakan, yang diikuti oleh kebijakan lainnya oleh pemerintah daerah. Respon cepat dan tepat sangat dibutuhkan untuk mengatasi masalah ini. Pemerintah menghimbau kepada masyarakat agar selalu mematuhi protokol kesehatan, mengikuti kebijakan PPKM (Pemberlakuan Pembatasan Kegiatan Masyarakat), dan program vaksinasi digalakkan. Saat ini, pemerintah menyakini bahwa vaksinasi memiliki peran sentral dalam penanganan Covid-19 yaitu dengan tercapainya herd immunity masyarakat yang dapat mencegah kemungkinan terinfeksi virus. ${ }^{1}$ Untuk mendukung hal tesebut, pemerintah

1 Kementrian Komunikasi dan Informasi RI., "Pemerintah Terus Dorong Pengendalian Laju Penyebaran Covid-19," 20 Agustus, 2021, https://www.kominfo.go.id/content/detail/36050/p emerintah-terus-dorong-pengendalian-lajupenyebaran-covid-19/0/berita.

${ }^{2}$ Amir Baihaqi, "Pj. Bupati Sidoarjo: Penanganan COVID-19 Tentukan Keberhasilan Pembangunan," mengadakan program vaksinasi gratis yang bekerja sama dengan berbagai instansi.

Program vaksinasi gratis yang dilakukan oleh pemerintah pusat, kemudian diikuti oleh pemerintah daerah dan terus digalakkan, tidak terkecuali di wilayah Kabupaten Sidoarjo. Kabupaten Sidoarjo merupakan wilayah di provinsi Jawa Timur yang termasuk dalam zona merah dalam kurun waktu yang lama, hal ini diakui oleh Hudiyono selaku pejabat Bupati Sidoarjo. ${ }^{2}$ Kabupaten Sidoarjo merupakan wilayah dengan tingkat penduduk tinggi dan merupakan salah satu kota sibuk setelah Surabaya dan Gresik di Provinsi Jawa Timur. Dari data yang diambil per 10 Agustus 2021 sebanyak 22.594 orang positif terinfeksi virus Covid19 dan 839 orang meninggal dunia. ${ }^{3}$ Hal ini dikarenakan tingkat mobilitas masyarakat Sidoarjo yang tinggi, dan rata-rata masyarakat Sidoarjo berkerja di kota Surabaya, sementara Surabaya juga merupakan zona merah sehingga penyebaran Covid-19 semakin tidak terelakkan.

Adanya program vaskin gratis, diharapkan membantu Sidoarjo dan semua wilayah untuk menekan penyebaran Covid-19. Namun, masih banyak masyarakat yang meragukan dan bahkan skeptis terhadap pentingnya vaksinasi sebagai upaya sentral dalam menangani pandemi Covid-19. Keraguan yang terjadi di masyarakat merupakan reaksi yang

Detik News, 6 Oktober, 2020, https://news.detik.com/berita-jawa-timur/d-

5202626/pj-bupati-sidoarjo-penanganan-covid-19tentukan-keberhasilan-pembangunan.

3 Pusat Informasi dan Komunikasi COVID-19 Kabupaten Sidoarjo, "Angka Kejadian," 20 Agustus, 2021, https:/covid19.sidoarjokab.go.id/ Welcome\#angka. 
wajar ${ }^{4}$, hal ini mengingat bahwa virus Covid-19 merupakan hal yang masih baru dan vaksin yang diberikan tentu juga masih baru. Kekhawatiran mengenai resiko kesehatan setelah melakukan vaksin, tidak bisa dipungkiri menjadi salah satu alasan.

Selain itu, masyarakat menerima informasi terlalu banyak dan bahkan saling bertabrakan yang berasal dari kelompok pro-vaksin dengan kelompok anti-vaksin. Hal ini tentu semakin memperkeruh keadaan dan menimbulkan kekhawatiran. Ledakan informasi yang terjadi ini melahirkan paradox of plenty yaitu keadaan dimana masyarakat kehilangan rasa percaya dan perhatiannya terhadap informasi di sekitarnya. Polemik terkait vaksin yang terjadi di tengah masyarakat ini, kemudian bisa membuat tingkat kesadaran masyarakat terhadap pentingnya vaksinasi Covid-19 menurun.

Dalam hal ini, peran media massa sebagai penyebar informasi dengan fungsi edukasi dan kontrol masyarakat sangat diperlukan untuk memberikan penjelasan dan penerangan mengenai vaksinasi Covid-19 di masyarakat agar menjadi penting. Serta mengolahnya agar aman dan tepat dikonsumsi oleh masyarakat. Penggunaan media komunikasi massa dilakukan untuk memberikan informasiinformasi yang bisa menambah pengetahuan masyarakat agar mampu menjaga dirinya. Menurut Joseph Nye $(2008)^{5}$, dalam tahap persiapan untuk

${ }^{4}$ Enggar Furi Herdianto, "Vaksin dan Pandemi Covid-19," Blog-Latest News FPSCS, 28 Desember, 2020, https://fpscs.uii.ac.id/blog/2020/12/28/vaksin-danpandemi-covid-19/

5 Joseph Nye S., "Public Diplomacy and Soft Power," The Annals of The American Academy 616, no 1 (March 2008); 95. menghadapi krisis, pemerintah harus memiliki kemampuan respon cepat dalam memberikan informasi dan jika terjadi kesalahpahaman atas informasi tersebut atau ada informasi yang menyesatkan maka harus segera dijawab. Hal ini dilakukan untuk mencapai kredibilitas atas informasi yang disebarkan sebagai syarat yang menjamin kebenaran dari informasi tersebut.

Kredibilitas harus dipastikan oleh pemerintah, karena memang pada era digital dengan teknologi komunikasi yang cepat, mudah dan murah, tidak dapat dipungkiri membuat informasi yang beredar menjadi sangat bervariasi dan hal tersebut bisa menimbulkan kebingungan yang mampu mendorong masyarakat untuk meragukan pentingnya vaksin Covid-19. Dalam hal ini, komunikasi yang kredibel memiliki peran yang krusial di tengah pandemi. Media massa memiliki peran dan pengaruh yang sangat besar dan diperhitungkan untuk membantu upaya pemerintah dalam menjalankan programprogramnya.

Penelitian sebelumnya, Syarifudin Akbar, 2021 dalam jurnalnya ${ }^{6}$ menyatakan bahwa media memiliki peran strategis dalam menghadapi persoalan yang terjadi, sehingga harus mampu menjadi alternatif sebagai sarana edukasi yang efektif dan efesien dalam menyasar masyarakat. Selain itu, penelitian lainnya oleh Komariya dan Subeki, 2016 ${ }^{7}$ juga

${ }^{6}$ Syarifuddin Akbar, "Media Komunikasi Dalam Mendukung Penyebarluasan Informasi Penanggulangan Pandemi Covid-19," Jurnal Kominfo 2, no. 1 (Juni, 2021): 73.

${ }^{7}$ Kokom Komariya dan Priyo Subekti, "Penggunaan Media Massa Sebagai Agen Sosialisasi Dinas Kesehatan Kabupaten Tasikmalaya dalam Meningkatkan Kesadaran Masyarakat akan 
menyebutkan bahwa peran media massa juga digunakan untuk meningkatan kesadaran masyarakat akan pentingnya imunisasi oleh Dinas Kesehatan Masyarakat Kabupaten Tasikmalaya dinilai penting untuk menjadi agen sosialisasi.

Ada begitu banyak penelitian terdahulu yang membahas mengenai peran media massa, lainnya misalnya oleh Rajagukguk dan Olifia, $2020^{8}$ yang membahas mengenai peran strategis yang dimiliki oleh media massa dimasa pandemi yang dinilai penting dalam mengedukasi masyarakat mengenai bahaya Covid-19.

Selanjutnya, self-awareness atau kesadaran diri masyarakat juga merupakan salah satu faktor penting dalam menekan penyebaran Covid-19. Self-awareness merupakan kecerdasan mengenai alasanalasan pemahaman diri sendiri sehingga mampu menempatkan diri sesuai dengan situasi dan kondisi tertentu mengenai apa yang harus dilakukan. ${ }^{9}$ Minimnya kesadaran diri masyarakat menjadikan masyarakat kurang waspada akan ancaman yang ada. Masyarakat tanpa kesadaran akan kebingungan dalam menentukan sikap atas situasi dan kondisi yang terjadi. Sebaliknya jika masyarakat memiliki kesadaran diri yang tinggi, maka masyarakat akan mampu menentukan sikap yang tepat sesuai dengan keadaan.

Pentingnya Imunisasi," Jurnal Ilmiah Program Studi Hubungan Masyarakat 1, no. 1 (Agustus, 2016), 13.

${ }^{8}$ Solten Rajagukguk dan Sandra Olifia, "Peran Media Massa Terhadap Masyarakat di Saat Pandemi Covid-19," Jurnal IKOM USNI 2, no. 4 (September 2020): 42.

${ }^{9}$ M. Yudi Ali Akbar, et.al., "Hubungan Relijiusitas dengan Self Awareness Mahasiswa Program Studi
Pada penelitian sebelumnya, telah dibahas mengenai pentingnya mengembangkan tingkat kesadaran masyarakat dalam menghadapi ancaman pandemi Covid-19, karena jika tingkat kesadaran masyarakat tinggi dalam menjaga dirinya dari virus Corona maka secara tidak langsung akan sangat membantu negara dalam mengatasi ancaman kesehatan. ${ }^{10}$

Namun dari penelitian-penelitian tersebut belum ada yang membahas mengenai bagaimana peran media masssa dalam meningkatkan self-awareness masyarakat terhadap pentingnya vaksinasi Covid-19 di wilayah Kabupaten Sidoarjo.

Penelitian ini bertujuan untuk menjelaskan bagaimana peran media massa dalam meningkatkan self-awareness masyarakat ketika terjadi pardox of plenty terhadap pentingnya vaksinasi Covid-19 sebagai upaya sentral di Kabupaten Sidoarjo. Penjelasan mengenai peran media massa di era pandemi akan menambah pengetahuan masyarakat pada umumnya. Kemudian bagi pemerintah kabupaten (Pemkab) Sidoarjo pada khususnya agar dapat bermanfaat dalam pengambilan kebijakan-kebijakan, khususnya yang terkait dengan vaksinasi Covid-19.

\section{Peran Media Massa}

Media massa merupakan sarana atau alat yang dipergunakan dalam proses

Bimbingan Penyuluhan Islam (Konseling) UAI," Jurnal Al-Azhar Indonesia Seri Humaniora 4, no. 4 (September, 2018): 267.

10 Isa Sabrina dan Jerry Indrawan, "Mengembangkan Kesadaran Diri (SelfAwareness) Masyarakat untuk Menghadapi Ancaman Non-tradisional: Studi Kasus Covid-19," Jurnal Kajian Lemhannas RI., 8, no.2 (September 2020): 145 . 
komunikasi yang melibatkan banyak orang dengan cakupan yang luas. Media massa mengalami perkembangan pada setiap zaman dan menjadi esensi dari masyarakat. Hal ini juga diungkapkan oleh Mc.Luhan bersama Quentin Fiore, yang menyatakan bahwa media merupakan kepanjangan dari drama nanusia pada setia peranya. Terdapat empat era yaitu era kesukuan (lisan), era tulisan, era cetak, dan era elektronika. ${ }^{11}$ Sejalan dengan sejarahnya, jenis media massa meliputi media cetak, media elektronik dan media online. Media cetak (printed media) yaitu koran, majalah, buku, dan sebagainya, media elektronik (electronic media) yaitu televisi dan radio, kemudian media online (online media) yaitu internet seperti website atau blog.

Media massa sebagai sarana komunikasi massa memiliki fungsi untuk menginformasikan dan mengedukasi sekaligus menghibur masyarakat. Sehingga media dengan fungsi tersebut memiliki pengaruh terhadap masyarakat dalam menentukan arah pandang masyarakat terhadap suatu hal. Sejalan dengan fungsinya, lebih spesifik menurut Mc. Quail terdapat enam perspektif dalam melihat peran media, yaitu: ${ }^{12}$

1. Media dipandang sebagai jendela yang digunakan untuk melihat apa yang terjadi diluar dan mengetahui berbagai peristiwa diseluruh wilayah tanpa berada di tempat yang sama sehingga bisa merasakan pengalaman dan belajar melalui informasi-informasi tersebut. Dalam hal ini media massa

11 Sri Choiriyati, "Peran Media Massa dalam Membentuk Opini Publik," Jurnal Universitas Muhammadiyah Lampung 2, no. 2 (2015): 22. disebut sebagai window on event and experience.

2. Media merupakan cerminan berbagai peristiwa yang terjadi di masyarakat, terlepas dari baik atau buruknya informasi yang diberikan, media hanya berperan untuk merefleksikan apa yang terjadi yaitu sesuai fakta yang ada. Sehingga media sering di dianggap sebagai a mirror of event in society and the world, implying a faithful reflection. Padahal yang dianggap sebagai cermin adalah framing atau angle yang sesungguhnya bisa diarahkan,

3. Media massa dipandang sebagai penyaring informasi atau filter yang menyeleksi berbagai hal yang harusnya diberikan panggung atau tidak. Dalam hal ini, media bisa dikatakan sebagai gatekeeper atau penjaga agar bisa memilih (menseleksi) suatu informasi mana yang layak untuk dikonsumsi oleh masyarakat umum, dan mana yang tidak.

4. Media dilihat sebagai guide atau petunjuk yang menunjukkan arah atas kebingungan dan ketidak pastian serta mampu menerjemahkan peristiwa yang terjadi.

5. Memandang media massa sebagai forum untuk memberikan berbagai informasi dan ide-ide kepada masyarakat, sehingga ada umpan balik atau tanggapan dari informasi yang diberikan.

6. Media massa dipandang bukan hanya sekedar tempat lalu-lalang informasi,

${ }^{12}$ Silvia Riskha Fabriar, "Etika Media Massa," AnNida; Jurnal Komunikasi Islam .6, no. 1 (Januari 2014): 73. 
tetapi juga sebagai partner komunikasi yang memungkinkan terjadinya suatu komunikasi yang interaktif.

Dalam penelitian ini, ke-enam perspektif tersebut akan digunakan dalam melihat bagaimana peran media massa dalam meningkatkan kesadaran masyarakat akan pentingnya vaksinasi Covid-19.

\section{Self-Awareness}

Kesadaran diri atau self-awareness merupakan kecerdasan memahami diri sendiri yang mana mampu menunjukkan kejelasan dan pemahaman tentang perilaku diri. Kecerdasan memahami diri sehingga dapat menempatkan diri mereka sesuai dengan kondisi dan situasi tertentu, serta apa yang harus dilakukan. Menurut Bradberry Greaves tahun $2005^{13}$ kesadaran diri adalah kemampuan memahami emosi diri sendiri dalam berbagai kondisi dan situasi secara tepat dan akurat. Reaksi emosi saat menghadapi situasi tertentu dan respon apa yang akan diberikan baik secara positif maupun negative akan dipahami oleh kecerdasan pemahaman diri yang kita sebut dengan Kesadaran diri. Kesadaran ini bukan hanya peka pada emosi diri saja, tapi juga pada lingkungan sekitar dan orang lain.

Dalam psikologi, self-awareness terbagi menjadi dua jenis yaitu public selfawareness dan private self-awareness. ${ }^{14}$ Public self-awareness atau kesadaran diri

${ }^{13}$ M. Yudi Ali Akbar, et.al., "Hubungan Relijiusitas dengan Self Awareness Mahasiswa Program Studi Bimbingan Penyuluhan Islam (Konseling) UAI," Jurnal Al-Azhar Indonesia Seri Humaniora 4, no. 4 (September, 2018): 268.

${ }^{14}$ Kendra Cherry, "Self-Awareness Development and Types," Verry Well, diakses 14 Juli, 2020, publik adalah ketika seseorang mampu menyadari bagaimana penampilan mereka di publik. Kesadaran jenis ini memaksa individu untuk mematuhi norma-norma sosial yang berlaku. Individu akan sadar bahwa dirinya sedang diawasi dan dievaluasi oleh banyak orang, sehingga dirinya akan mencoba berperilaku sesuai dengan apa yang diinginkan dan diterima secara sosial. Selanjutnya, private selfawareness atau kesadaran diri pribadi merupakan kesadaran atas pemikiran dan ingatnya sendiri. Individu akan berfokus pada dirinya sebagai objek perhatian, disini individu akan sadar atas peran dan tanggung jawabnya. Keduanya saling berkaitan karena pada dasarnya manusia harus sadar atas diri sendiri dan juga lingkungan sekitarnya.

\section{Vaksinasi Covid-19}

Vaksinasi merupakan proses pemasukan vaksin ke dalam tubuh manusia. Vaksin sendiri adalah produk yang terbuat dari komponen antigen (mikroorganisme) khusus yang sudah dilemahkan untuk merangsang pembentukan antibody agar mampu bertahan menghadapi serangan virus penyakit. Bahan dasar membuat vaksin tentu saja memerlukan mikroorganisme berupa virus atau bakteri yang dikembangbiakkan dan akan dipanen, dilemahkan, dimurnikan serta diformulasikan untuk diedarkan ${ }^{15}$. (Biofarma, "Vaksin.”). Tentunya dalam

https://www.verywellmind.com/what-is-selfawareness-2795023

${ }^{15}$ BUMN Farmasi Biofarma., "Vaksin," diakses 18 November, 2021 , https://www.biofarma.co.id/id/researcher/detail/va ksin. 
pembuatan vaksin diawasi oleh regulasi pembuatan obat yang baik agar aman diterima tubuh manusia.

Dalam hal ini vaksinasi merupakan upaya untuk mencegah penularan virus penyakit, termasuk virus Covid-19. Virus Covid-19 sendiri merupakan jenis baru yang muncul pada akhir tahun 2019. Sehingga perlu adanya penelitian secara mendalam mengenai virus ini agar dapat ditemukan vaksin yang aman dan tepat untuk menghadapinya. Atas upaya yang dilakukan dan kolaborasi global yang digiatkan, organisasi kesehatan dunia (WHO) pada 31 Desember 2020 memberikan izin pertamanya pada vaksin Covid-19 buatan Pfizer/BioNTech. Kemudian dalam perkembangannya, saat ini sudah ada lebih banyak jenis vaksin untuk Covid-19 yang tentunya sudah dijamin aman karena sudah melewati tahap pengujian sesuai standar keamanan tertinggi WHO. ${ }^{16}$

Program vaksinasi Covid-19 di Indonesia mulai dilakukan pada awal tahun 2021, dan digiatkan oleh pemerintah sebagai upaya pemutusan rantai penyebaran virus corona. Terdapat empat tahap dalam melakukan vaksinasi Covid-19 yaitu: pertama, pendaftaran dan verifikasi data; kedua, pemeriksaan kesehatan sederhana; ketiga, menerima suntikan vaksin, dan keempat, pencatatan usai vaksin, yaitu menunggu selama 30 menit untuk antisipasi efek samping vaksinasi. Vaksinasi akan aman dilakukan dan tidak menimbulkan efek samping jika sesuai dengan standar dan syarat penerimaan vaksinasi.

${ }^{16}$ World Health Organization., "Coronavirus disease (COVID-19): Vaccines," diakses 24 Agustus, 2021, https://www.who.int/news-room/qa-detail/coronavirus-disease-(covid-19)-vaccines

\section{Metode Penelitian}

Penelitian ini menggunakan metode penelitian gabungan (mixed methods) dalam rangka menjelaskan bagaimana peran media massa dalam meningkatkan self-awareness masyarakat terhadap pentingnya vaksinasi Covid-19 di Kabupaten Sidoarjo. Desain penelitian campuran yang digunakan adalah concurrent triangulationya yaitu dengan teknis mengumpulkan data kuantitatif dan kualitatif dalam satu waktu, dan hasilnya akan diinterpretasi bersama secara seimbang. ${ }^{17}$

Pengumpulan data kuantitatif dilakukan melalui kuesioner google form yang disebar pada tanggal 8 hingga 15 Agustus 2021. Kuesioner ditujukan pada masyarakat dengan usia diatas 18 tahun di wilayah kabupaten Sidoarjo. Kuesioner berisi pertanyaan-pertanyaan mengenai tiga konsep yaitu peran media massa, selfawareness dan pengetahuan mengenai vaksinasi Covid-19. Jumlah pertanyaan ada 26 butir dan diiisi oleh 117 responden.

Kemudian, data kualitatif diperoleh melalui studi dokumentasi dan riset online (online research). Studi dokumentasi yaitu pengumpulan data berbasis dokumen dengan cara membaca, mempelajari, meneliti, mengkaji, serta menelaah literatur-literatur berupa buku, jurnal, makalah dan segala dokumen arsip lalu mengolahnya untuk menjadi bahan dalam penelitihan. Riset online adalah pencarian data atau informasi berbasis online dengan menggunakan Google dan Google Scholar. Penggunaan internet untuk mengumpulkan

${ }^{17}$ John W. Creswell, Research Design: Pendekatan Metode Kuantitatif, Kualitatif dan Campuran, Ed. 4. (Yogyakarta: Pustaka Pelajar, 2016), 297. 
informasi dan data akan mendukung penelitian dan memperluas referensi yang akan didapat. ${ }^{18}$

Analisis data yang dilakukan adalah interpretasi konsep dari keseluruhan data yang didapat baik data kuantitatif dan kualitatif, dengan menggunakan strategi analitik yang bertujuan untuk mengubah atau menterjemahkan data mentah ke dalam bentuk uraian atau deskripsi dan eksplanasi dari fenomena yang sedang diteliti dan dipelajari. Dalam penelitihan ini, peneliti mengumpulkan, mempelajari dan menganalisis data yang berkaitan dengan peran media massa dalam meningkatkan self-awareness masyarakat terhadap pentingnya vaksinasi Covid-19.

Uji keabsahan data dilakukan untuk menjaga nilai kebenaran atau kredibilitas dari data yang diperoleh. Hal ini menjadi penting untuk dilakukan karena dengan kredibilitas data, maka penelitian akan mendapat jaminan untuk dapat dipercaya. Dalam mencapainya, peneliti melakukan Triangulasi dengan perpanjangan pengamatan dan ketekunan. Triangulasi yaitu pengecekan data dari berbagai sumber dengan berbagai cara dan berbagai waktu. ${ }^{19}$ Dalam penelitihan ini, peneliti berulangkali mengecek data atau informasi yang dikumpulkan melalui berbagai sumber baik dari web Pemkab Sidoarjo, situs berita, web kominfo, kemenkes dan juga web swasta lainnya. Adapun teknik yang digunakan dalam penelitian tidak hanya dari teknik pengumpulan data internet berupa berita dan jurnal penelitian, tapi juga juga

${ }^{18}$ Umar Suryadi Bakry, Metode Penelitihan Hubungan Internasional, (Yogyakarta: Pustaka Pelajar, 2016), 176. langsung melakukan re-check ke web resmi pihak terkait.

\section{Hasil dan pembahasan}

Informasi merupakan data atau fakta yang memiliki nilai sehingga dapat mempengaruhi individu atau kelompok dalam mengambil suatu keputusan. Dalam hal ini media massa merupakan kunci dalam mendapatkan berbagai informasi. Sehingga tak heran jika kehidupan masyarakat dengan media massa tidak dapat dipisahkan. Media massa memiliki posisi dan perannya dalam masyarakat yang erat kaitannya dengan fungsi yang dimiliki yaitu menginformasikan, mengedukasi serta menghibur. Dengan peran yang dimilikinya tersebut maka media massa tentu punya pengaruh. Pengaruh dari peran media memiliki kekuatan besar yang dapat diperhitungkan, dan hal ini yang kemudian bisa dimanfaatkan oleh pemerintah dalam mendukung implementasi kebijakan, khususnya dalam upaya pencegahan penyebaran Covid-19.

Dari hasil penelitian yang didapat yaitu sebanyak 117 responden dengan karakteristik; responden yang berjenis kelamin laki-laki sebanyak 23,9\% dan perempuan sebanyak $76,1 \%$, berumur 18 tahun hingga 42 tahun yang tersebar di 18 kecamatan di Kab. Sidorajo, Responden menyakini bahwa media massa memiliki peran dalam mendapatkan informasi yang membantu dalam kehidupan sosial. Hal ini dapat dibuktikan melalui intensitas persepsi masyarakat Sidoarjo yang

${ }^{19}$ Sugiyono, Metode Penelitian Kebijakan: Pendekatan Kuantitatif, Kualitatif, Kombinasi, $R \& D$ dan Penelitihan Evaluasi, (Bandung: CV. Alfabeta, 2017), 257. 
sebanyak $84 \%$ merasa sering mendapat bantuan melalui informasi media massa, $13,7 \%$ merasa jarang dan $1,7 \%$ merasa tidak terbantu.

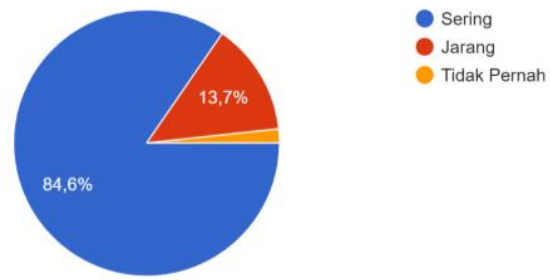

Grafik 1. Intensitas Responden Mendapat Bantuan Informasi dari Media Massa

Dalam grafik.1 dapat dipahami bahwa hampir keseluruhan responden setuju memandang media massa adalah sarana yang seringkali membantu dalam mendapatkan informasi di kehidupan sehari-hari. Peran media massa dalam menginformasikan ini akan berguna untuk mengedukasi masyarakat mengenai informasi-informasi penting, termasuk mengenai Covid-19. Hal ini juga dapat dipahami jika kita kembali pada definisi awal media massa. Media massa merupakan sarana komunikasi massa yang tidak dapat dipungkiri memiliki peran strategis dalam kehidupan sosial masyarakat. Peran yang dimiliki oleh media massa tentu terkait dengan fungsi yang dimiliki.

Menurut Nuruddin ${ }^{20}$ media massa memiliki fungsi sosial yaitu sebagai kontrol sosial, fungsi interpretasi, fungsi transmisi dan fungsi hiburan. Sehingga ditengah kondisi pandemi, fungsi tersebut lebih diperjelas yaitu:

Pertama, fungsi kontrol sosial yang dimiliki oleh media massa digunakan untuk mengawasi informasi mengenai Covid-19 terutama mengenai hoax yang tersebar di masyarakat. Kedua, fungsi interpretasi yaitu media massa memiliki fungsi untuk memaknai sebuah peristiwa atau informasi sehingga mudah diterima oleh masyarakat. Ketiga, fungsi transmisi yaitu untuk mengirimkan pesan atau informasi kepada masyarakat luas. Dalam hal ini, media massa merupakan jembatan penghubung antara informasi yang diberikan pemerintah atau ahli kepada masyarakat mengenai Covid-19 dan juga vaksinasi Covid-19. Keempat, fungsi hiburan kepada masyarakat untuk mengurangi kejenuhan masyarakat akibat situasi Covid-19, hal ini agar bisa mengimbangi informasi-informasi berat yang disajikan. Melihat dari fungsinya, media massa bukan hanya sarana untuk pengalihan atau pelepasan ketegangan (fungsi hiburan) tetapi juga memiliki banyak fungsi lainnya.

Pengaruh media massa ini kemudian memiliki posisi strategis dalam menghadapi pandemi Covid-19 karena manusia sebagai objek dan subjek dalam proses komunikasi menjadi sasaran dalam kebijakan untuk mencegah penyebaran coronavirus. Peran media massa pada suatu titik, dianggap membentuk keberagaman budaya, karena pengaruhnya yang berimbas pada sistem nilai dan perilaku masyarakat. Dampak yang dibawa oleh media massa dapat membawa perubahan yang signifikan dalam kehidupan sosial masyarakat, sehingga memungkinkan untuk media massa mempengaruhi realitas sosial.

Hasil penelitian juga membuktikan bahwa $48,7 \%$ responden menyatakan seringkali terpengaruh oleh informasi

\footnotetext{
${ }^{20}$ Fabriar, "Etika Media Massa," 72.
} 
media massa dalam mengambil tindakan lebih lanjut.

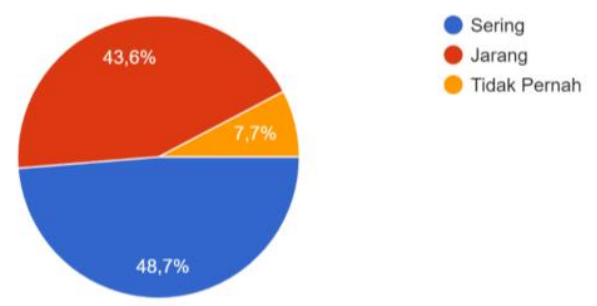

Grafik 2. Intensitas Peran Media Massa Mempengaruhi Tindakan Responden

Dari grafik 2 diatas dapat dipahami bahwa masyarakat tidak memungkiri tidak jarang menggunakan informasi dari media massa untuk menentukan tindakan apa yang akan diambilnya. Intensitas yang menunjukkan 48,7\% sering, $43 \%$ jarang dan hanya $7,7 \%$ tidak pernah. Sehingga dapat dipahami bahwa media massa memang memiliki peran yang krusial dalam kehidupan masyarakat, sampai bisa mempengaruhi individu dalam bertindak. Bertindak di sini bisa secara pribadi mauapun sosial. Hal ini pada dasarnya sudah termasuk pada peran media massa sebagai guide yang menunjukkan arah dalam pengambilan tindakan. Dengan peran penting yang dimiliki oleh media massa, tentunya sebanding dengan dampak yang akan dihasilkan.

Peran media massa dimanfaatkan oleh pemerintah untuk berbagai hal yang mendukung kebijakan. Berdasarkan data yang didapatkan dari web resmi ${ }^{21}$, Pemkab Sidoarjo menjalin kerja sama kemitraan dengan 13 media cetak harian, 20 media elektronik yaitu televisi dan radio, 19

\footnotetext{
${ }^{21}$ Kabupaten Sidoarjo, "Mitra Media," diakses 24 Agustus, 2021 , http://www.sidoarjokab.go.id/mitra-media.

${ }^{22}$ Rokom, "Vaksin COVID-19 Merek Sinovac, AstraZeneca, Pfizer, dan Novavax Tidak Dapat
}

media online, dan 8 media mingguan. Sidoarjo memiliki lebih dari cukup mitra media massa sebagai corong pemberitaan guna menyampaikan berbagai informasi kepada masyarakat, khususnya mengenai pentingnya vaksinasi Covid-19. Kemitraan dengan media massa dapat diartikan sebagai pengakuan peran media massa oleh Pemkab Sidoarjo. Kemitraan ini akan membantu dalam memberikan informasi yang mampu mengedukasi masyarakat. Selain itu, juga akan membantu memaksimalkan peran media massa dalam membantu penanganan pandemi Covid-19. Salah satunya adalah upaya untuk meningkatkan kesadaran masyarakat akan pentinganya vaksinasi Covid-19. Seperti diketahui bahwa vaksinasi Covid-19 merupakan sebuah upaya sentral untuk menekan penyebaran virus covid-19.

Vaksinasi merupakan cara paling efektif dan ekonomis dalam mencegah penyebaran penyakit menular, tidak terkecuali pandemi Covid-19. Vaksin terbuat dari mikroorganisme yang sudah diinaktiviasi sehingga dapat diterima dan membentuk antibodi. Antibodi sebagai kekebalan tubuh akan mampu melindungi diri dari virus penyakit tertentu. Dalam hal ini vaksinasi merupakan jalan keluar yang sedang banyak diusahakan oleh pemerintah dalam menghadapi Covid-19. Untuk saat ini ada 13 jenis vaksin yang tesedia dan diantaranya masuk ke Indonesia yaitu vaksin jenis Moderna, Sinovac, Astra Zeneca, Sinopharm, Pfizer, dan Novavax. ${ }^{22}$

Dipergunakan untuk Vaksinasi Gotong Royong," Sehat Negeriku Kemenkes, 15 Juni, 2021, https://sehatnegeriku.kemkes.go.id/baca/beritautama/20210615/1837903/vaksin-covid-19-mereksinovac-astrazeneca-pfizer-dan-novavax-tidak- 
Program vaksinasi Covid-19 di Sidoarjo dibuka untuk masyarakat umum dengan usia diatas 18 tahun. Adpun jenis vaksin yang digunakan adalah Astrazeneca, Sinovac dan Moderna yang terbagi menjadi dosis 1,2 , dan $3 .^{23}$ Vaksin dosis 3 banyak diberikan kepada tenaga kesehatan, sedangkan untuk masyarakat umum diberikan dosis 1 dan 2. Program vaksinasi Covid-19 di wilayah Kab. Sidoarjo ditargetkan sebesar 1,7 juta jiwa pada dosis pertama. Namun, Sidoarjo belum mencapai hasil yang memuaskan berdasarkan data dari Satgas Covid-19 Provinsi Jawa Timur. ${ }^{24}$ Vaksinasi dosis pertama hanya menembus angka 537,756 orang atau $33,31 \%$ dari target dan dosis kedua lebih sedikit lagi yaitu baru 283,492 atau $17,56 \%$ dari target.

Tentunya hal tersebut cukup mengkhawatirkan untuk keberhasilan upaya penekanan penyebaran Covid-19 di Sidoarjo. Salah satu hal yang membuat kurangnya minat masyarakat untuk menerima vaksin Covid-19 adalah tidak menganggap bahwa vaksin merupakan hal yang penting dan sentral yang harus segera dilakukan. Hal tersebut terjadi karena masyarakat masih belum memiliki kepercayaan terhadap keefektifan dan keamanan vaksin. Masyarakat umum masih banyak merasa takut untuk di vaksin, mereka khawatir akan ada efek samping usai melakukan vaksinasi covid19. Sehingga masyarakat lebih banyak menghindar untuk melakukan vaksin jika

dapat-dipergunakan-untuk-vaksinasi-gotongroyong/.

${ }^{23}$ Yantina Debora, "Lokasi Vaksin Corona Sidoarjo 26-30 Agustus 2021 Dosis 1, 2 dan 3," Tirto.id, 26 Agustus, 2021, https://tirto.id/lokasi-vaksincorona-sidoarjo-26-30-agustus-2021-dosis-1-2dan-3-giYl tidak memiliki kepentingan, sepert iuntuk syarat bekerja atau berpergian.

Polemik mengenai vaksinasi masih terus berlanjut dan menghambat upaya pemerintah dalam menghadapi pandemi Covid-19 dan membebaskan wilayah Sidoarjo dari zona merah. Masih banyak pro dan kontra yang menyertai munculnya vaksin Covid-19. Hal ini merupakan hal wajar ketika ditemukannya sesuatu yang baru ditengah kondisi yang bisa dikatakan baru juga. Kepercayaan mengenai keefektifan vaksin Covid-19 masih di pertanyakan. Selain itu, kekhawatiran terkait keamanan dan resiko kesehatan setelah vaksinasi Covid-19 menjadi pertimbangan dalam kesediaan menerima vaksinasi.

Menurut data hasil penelitian menunjukkan bahwa sebesar $47 \%$ masyarakat memiliki keraguan terhadap keefektifan vaksin Covid-19 mampu mencegah terinfeksi Covid-19. Bahkan ada $11,1 \%$ masyarakat yang menyangkal keefektifan vaksin Covid-19. Hal ini menunjukkan bahwa tingkat kepercayaan masih kurang dan keraguan masih mendominasi masyarakat.
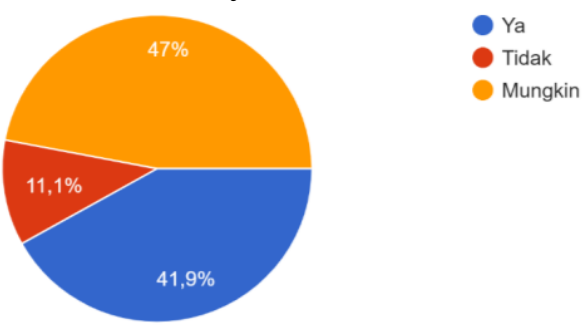

Grafik 3. Tingkat Kepercayaan Masyarakat Terhadap Keefektivan Vaksin Covid-19

\footnotetext{
${ }^{24}$ Runik Sri Astuti, "Sidoarjo Kerahkan Tim Percepatan Vaksinasi Covid-19 hingga Penjemputan Isoman," Kompas.id, diakses 24 Agustus, 2021 , https://www.kompas.id/baca/nusantara/2021/08/18 /sidoarjo-kerahkan-tim-percepatan-vaksinasicovid-19-hingga-penjemputan-isoman/.
} 
Selain itu data juga menunjukkan bahwa masyarakat meyakini jika vaksinasi Covid-19 akan memilik iefek samping seusai pelaksanaannya. Lebih dari $50 \%$ masyarakat percaya bahwa vaksinasi memiliki efek msamping. Ini bukanlah angka yang kecil, sehingga bukanlah hal yang mengherankan jika program vaksinasi Covid-19 PemkabSidoarjo masih jauh dari kata memuaskan.
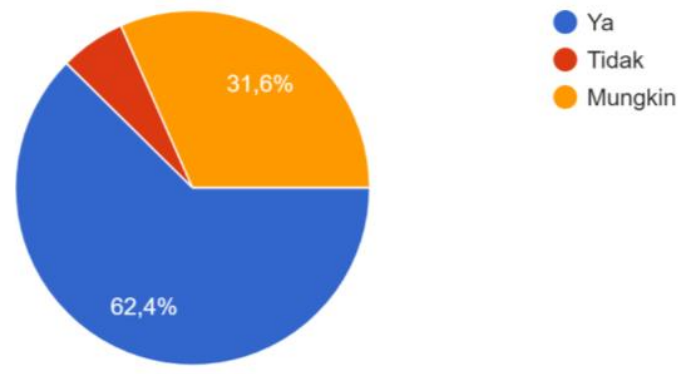

Grafik 4. Tingkat Keyakinan Masyarakat TerhadapAdanyaEfekSampingVaksin Covid-19

Lebih lanjut, keraguan dan kekhawatiran mengenai vaksin covid-19 diperburuk dengan ledakan informasi tanpa filter sehingga tercampur dengan hoax yang semakin membingungkan masyarakat. Ledakan informasi akan menimbulkan paradox of plenty yaitu kurangnya perhatian masyarakat terhadap informasi atau berita peristiwa terkini. Kurangnya perhatian dan kepercayaan masyarakat akan secara otomatis menurunkan tingkat kesadaran masyarakat dalam menentukan sikap. Termasuk kesadaran masyarakat $\mathrm{m}$ akan pentingnya vaksin Covid-19. Hal ini akan mengakibatkan kurangnya minat masyarakat untuk menerima vaksin covid19 dan tentunya akan berimbas pada keberhasilan pemerintah dalam upaya penanggulangan Covid-19 di Sidoarjo.

Dalam hal ini masyarakat masih sangat perlu pengetahuan mengenai vaksin
Covid-19 agar bisa membangun kepercayaan masyarakat terhadap vaksinasi Covid-19. Menurut hasil penelitian membuktikan bahwa masyarakat merasa kurang informasi dan masih membutuhkan informasi lebih lanjut mengenai vaksin Covid-19. Berdasarkan Grafik 5. Menunjukkan sebesar 82,9\% masyarakat sepakat bahwa informasi lebih lanjut terutama terkait keamanan dan keefektifan vaksin Covid-19 masih dibutuhkan. Dengan adanya informasi lebih lanjut tentu akan mengedukasi serta berimbas pada tingkat kesadaran masyarakat akan pentingnya vaksinasi Covid-19.

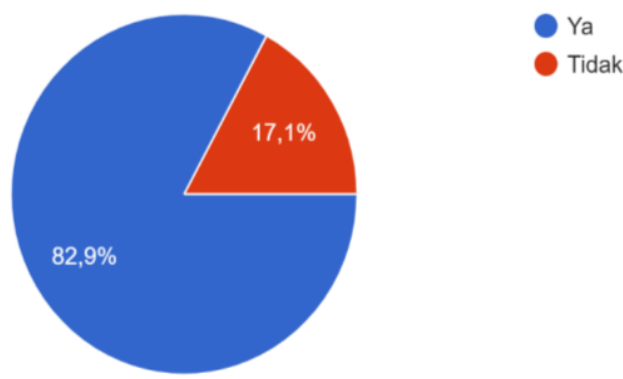

Grafik 5. Tingkat Kebutuhan Informasi LanjutanTerkaitVaksin Covid-19

Jika melihat masih banyak kerancuan infomasi yang menyebabkan keraguan hingga ketidakacuhan atas pentingnya vaksinasi Covid-19. Maka bisa dikatakan bahwa peran media massa dalam mengedukasi masih kurang dioptimakan. Hal ini akan berimbas pada kesadaran diri atau self-awareness masyarakat. Karena pada dasarnya informasi yang disebarkan oleh media massa dapat mempengaruhi pemahaman masyarakat akan suatu hal. Pemahaman tersebut kemudian menjadi reason bagi individu dalam mengambil sikap, yang mana dalam hal ini adalah kesediaan menerima vaksin. Karenanya pemahaman mengenai vaksinasi covid-19 
perlu digalakkan oleh media secara tepat, agar informasi tentang vaksinasi tidak tumpang tindih.

Ketika seseorang memiliki tingkat kesadaran diri yang tinggi maka mereka cenderung mengaitkan dirinya kepada sistem nilai yang berkembang di sekitarnya. Mereka akan mampu merefleksikan dirinya sesuai dengan nilainilai positif yang dianut. Sedangkan jika seseorang memiliki tingkat kesadaran diri yang rendah maka akan cenderung tidak mampu menghargai dan mengontrol dirinya dan hal tersebut akan menjadi hambatan bagi mereka untuk memiliki hubungan sosial yang baik. ${ }^{25}$

Dalam hal ini dapat dipahami bahwa kesadaran diri memiliki bagian yang penting dalam kehidupan. Masyarakat yang memiliki kesadaran diri tinggi terhadap kondisi pandemi tentu akan cenderung mengerti bahwa vaksinasi merupakan hal yang penting dilakukan. Hal ini akan mendorong masyarakat untuk melakukan vaksinasi, karena sadar bahwa dirinya yang merupakan bagian dari sosial sangat penting untuk mengikuti aturan dan himbauan yang dilakukan pemerintah untuk melakukan vaksinasi Covid-19.

Kesadaran diri bisa dibangun dengan menggunakan peran media massa yaitu melalui informasi atau berita yang disampaikan. Kesadaran diri bisa dibangun dengan pengetahuan yang dimiliki. Disinilah peran media massa untuk mengedukasi masyarakat mengenai vaksinasi Covid-19. Media massa bisa menjadi agen sosialisasi yang menjelaskan

${ }^{25}$ Rachman Bayu Hilmawan, "Hubungan Self Awareness Dengan Deindividuasi Pada Remaja Pengguna Digital Piracy," Skripsi (Fakultas apa saja yang dipertanyakan oleh masyarakat terkait vaksin Covid-19. Menurut data hasil penelitian, masyarakat dalam mencari informasi atau berita terkait vaksinasi Covid-19 lebih banyak menggunakan website berita online yaitu sebesar $67,5 \%$ yang kemudian disusul oleh Tv sebesar 46,2\% dan website pemerintah di urutan ketiga sebesar $29,1 \%$. Ketiganya lebih banyak menjadi pilihan masyarakat dalam mencari informasi terkait vaskin Covid-19.

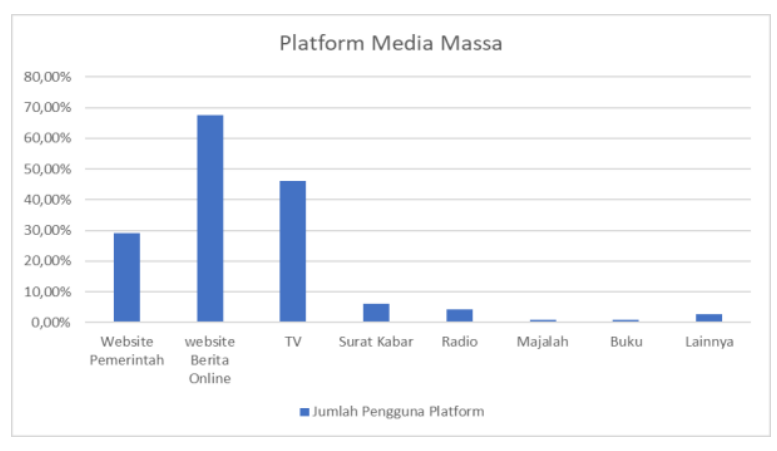

Grafik 6. JumlahPengguna Platform Media Massa oleh Masyarakat

Dengan angka tersebut bias dipahami bahwa media massa memiliki peluang untuk lebih mengoptimalkan peran yang dimiliki agar dapat meningkatkan kesadaran diri masyarakat terhadap pentinganya vaksin Covid-19. Peran media massa yang harus dioptimalkan untuk mengatasi situasi yang terjadi, yaitu kurangnya kesadaran akibat paradox of plenty, lebih berfokus pada peran sebagai guide dan gatekeeper.Keduanya dapat mengatasi masalah kebingungan informasi akibat hoax yang beredar luas dengan memfilternya, terutama hoax mengenai kematian karena vaksin covid-19 dan bahaya vaksin Covid-19 yang

Psikologi dan Kesehatan UIN SunanAmpel Surabaya: 2018): 23. 
mengkhawatirkan masyarakat. Kemudian mengarahkan masyarakat untuk menerima informasi-informasi yang sesungguhnya sehingga memberikan kejelasan yang diharapkan oleh masyarakat,

Sehingga, peran media sangat diperlukan ketika masyarakat dihadapkan pada pilihan yang membingungkan antara menerima atau menolak vaksin covid-19 ditengah kondisi ledakan informasi. Namun demkian, sebenarnya keenam peran media massa semuanya dibutuhkan oleh masyarakat. Hal ini juga untuk menjaga keseimbangan informasi yang beredar di masyarakat. Pertama, media massas ebagai window on event and experience, berperan sebagai pemasok informasi atau berita mengenai Covid-19, termasuk mengenai program vaksinasi Covid-19 kepada masyarakat. Kab. Sidoarjo memiliki berbagai website yang membagikan banyak informasi dan keterbukaan sistem pelayanan pemerintahan, yaitu di http://www.sidoarjokab.go.id, dan untukhttps://covid19.sidoarjokab.go.id merupakan website khusus informasi mengenai covid-19 di Sidorajo yang selalu di update.

Selain kedua website resmi tersebut, mitra media Sidoarjo seperti kompas.com, Detik.com, Jawa Pos, JTV, Radar Surabaya, Sidoarjo Terkini, dan lain sebagainya dengan total 60 mitra media dari berbagai jenis media massa mulai dari media cetak harian dan mingguan, media elektronik, hingga media online. Mitra media tersebut juga merupakan jendela informasi yang disediakan oleh Pemerintah Kabupaten (Pemkab) Sidoarjo untuk masyarakat. Media massa selalu memberikan update berita terbaru. Hal ini akan memberikan pengetahuan yang lebih luas kepada masyarakat agar mampu memahami situasi dan kondisi serta mampu menentukan sikap yang tepat dalam menghadapi krisis.

Kedua media massa sebagai refleksi realitas, dalam hal ini media massa berperan memberikan informasi yang sesuai fakta dilapangan. Media massa di website resmi Pemkab Sidoarjo memberikan informasi mengenai Covid-19 dan Vaksinasi Covid-19, perkembangan terkini mengenai pasien yang terinfeksi, sembuh, meninggal, dan suspect terus disampaikan. Angka yang terlihat digrafik pun selalu naik baik dari pasien terifeksi maupun pasien yang sembuh.

Ketiga, sebagai gatekeeper, media massa berperan memfilter atau menyaring informasi yang beredar di masyarakat, bukan berarti membatasi tapi lebih mengarah pada penjagaan masyarakat agar terhidar dari informasi bohong, yang berbeda dari kenyataan atau biasa disebut hoax. Dalam hal ini Pemkab Sidoarjo bersama Kapolersta Sidoarjo mengajak pihak media untuk memerangi berita hoax yang beredar. Karena pada dasarnya media massa memiliki kode etik pers dan komando memerangi hoax pun juga diberikan Dewan Pers Jawa Timur. Menyaring informasi yang akan disuguhkan kepada masyarakat agar terhindar dari berita hoax akan berdampak pada tingkat kredibilitas informasi dan bisa mengurangi paradox of plenty.

Keempat, media massa yang berperan sebagai guide yaitu menunjukkan arah dalam ketidak pastian, sehingga secara tidak langsung mampu 
mempengaruhi perilaku dan tindakan masyarakat. Media massa membantu Pemkab Sidoarjo untuk mengarahkan masyarakat dan meyakinkan masyarakat mengenai pentingnya menerima vaksinasi Covid-19. Pengarahan ini dilakukan melalui sosialisasi dan kampanye vaksin Ccovid-19 melalui website resmi maupun mitra media. Selain itu, informasi yang diberikan adalah sesuai para ahli atau tokoh dalam bidangnya yang sudah memiliki peran di tengah masyarakat. Jika pun terjadi kesalahan atau pembaharuan informasi dikarenakan virus yang tergolong baru dan butuh banyak penelitian, maka media massa berperan sebagai penjelas dan penerjemah terkait alasan kepada keadaan tersebut terjadi yang oleh Pemkab Sidoarjo dilakukan melalui website resminya.

Kelima, sebagai forum interaktif, media massa juga berperan untuk menjadi wadah bagi masyarakat untuk menyampaikan pendapat, pertanyaan dan keresahannya mengenai vaksin Covid-19. Dalam hal ini, Pemkab Sidoarjo melalui website resminya terkait Covid-19 menyediakan live chat untuk masyarakat, sehingga masyarakat dapat menanyakan atau menyampaikan keluhannya. Selain itu mitra media juga memiliki sistem masingmasing untuk menampung pendapat dari masyarakat, bisa melalui tulisan artikel, opini, dan poster yang dikirim ke salah satu mitra media Sidoarjo.

Keenam, sebagai partner komunikasi interaktif, media massa juga berperan untuk menjadi partner bagi masyarakat untuk menyampaikan pendapat, pertanyaan dan keresahannya mengenai vaksin Covid-19. Dalam hal ini biasanya keluhan-keluhan mengenai pelayanan vakisnasi disampaikan melalui website resmi Sidoarjo yaitu http://www.sidoarjokab.go.id pada umumnya dan https://covid19.sidoarjokab.go.id pada khususnya. Di layanan link ini ada fitur live chat untuk menanyakan semua hal terkait covid-19 dan vaksin covid-19.

Demikian, ke-enam peran yang dimiliki oleh media massa yang memiliki fungsinya masing-masing. Media massa yang mengoptimalkan peran yang dimilikinya akan memberikan dampak yang cukup untuk meningkatkan kesadaran diri atau self-awareness masyarakat. Dampak yang terjadi adalah secara kognitif akan menimbulkan sifat informative bagi masyarakat Sidoarjo mengenai pentingnya vaksinasi. Tentu saja hal ini akan membantu masyarakat untuk mendapat pengetahuan dan mengembangkan ketrampilan kognitifnya.

Kemudian secara efektif, dampak yang dimiliki media massa adalah dapat menarik perasaan emosional masyarakat agar pesan atau informasi yang diberikan bisa tersampaikan dengan baik. Hal ini berkaitan dengan peran media massa sebagai refleksi realitas, misalnya dengan memberitakan mengenai berita jumlah orang yang terinfeksi, jumlah tenaga kerja yang meninggalkan keluarganya demi tugas, dan berita mengenai meningkatnya jumlah anak yatim piatu akibat orang tuanya direnggut ganasnya Covid-19, semu ini diharapkan mampu membuat masyarakat terbuka pikirannya untuk berupaya bersama mengakhiri pandemi Covid-19, karena bisa merasakan emosi yang sama dengan para korban Covid-19. 
Kemudian secara kognitif atau behavioral, setelah mendapat informasi dan dapat merasakan perasaan yang sama, selanjutnya akan berpengaruh pada tindakan, perilaku atau kegiatan secara langsung. Setelah masyarakat Sidoarjo mendapat banyak informasi dan bisa sama rasa dalam menghadapi pandemi, pastinya akan memunculkan kesadaran diri dengan melakukan tindakan berdasarkan keinginan bersama untuk mengakhiri zona merah yang terjadi di Sidoarjo. Selain patuh terhadap protokol kesehatan, upaya lainnya yang terbukti cepat dan efektif dalam menekan penyebaran virus Covid19 adalah melalui vaksinasi Covid-19.

\section{Kesimpulan}

Media massa merupakan sarana komunikasi yang menargetkan masyarakat luas. Media massa memiliki peran dan fungsi yang dapat membantu masyarakat dalam mendapatkan edukasi pengetahuan dalam berbagai hal termasuk mengenai pengetahuan vaksinasi Covid-19. Sebanyak $84 \%$ masyarakat di Kabupaten Sidoarjo menyatakan bahawa informasi yang didapat melalui media massa membantu dalam kehidupan sosial mereka. Lebih lanjut, ada 48,7\% masyarakat menyatakan bahwa seringkali media massa mempengaruhi mereka dalam mengambil suatu tindakan, sedangkan 43,6 \% masyarakat merasa jarang terpengaruh, lalu sisanya $7,7 \%$ tidak merasa terpengaruh.

Pemerintah Kabupaten (Pemkab) Sidoarjo sendiri memiliki 60 mitra media dari berbagi jenis media massa mulai cetak, elektronik hingga media online. Dalam hal ini Pemkab Sidoarjo mengoptimalkan peran media massa sebagai corong informasi untuk menginformasikan program pemerintah, yang salah satunya adalah program vaksin gratis Covid-19.

Program vaksin Covid-19 masih belum mencapai target, sehingga peran media massa dalam hal ini yaitu: 1 . Sebagai jendela informasi media massa memberikan pengetahuan yang luas akan pentingnya vaksinasi Covid-19; 2. Sebagai refleksi realitas, media massa memberikan informasi sesuai fakta yang terjadi di lapangan; 3. Sebagai gatekeeper media massa menyaring informasi-informasi bohong (hoax) mengenai vaksin Covid-19; 4. Sebagai guide, media massa memberikan arahan dan kejelasan akan informasi yang beredar sesuai dengan ahli pada bidangnya; 5. Sebagai forum, media massa sebagai wadah untuk menampung segala keluhan, pendapat, dan pertanyaan masyarakat; dan 6. Sebagai partner komunikasi media massa menjadi wahana pertemuan untuk memberikan pernyataan dan pertanyaan, dari pemerintah kepada masyarakat semikian juga sebaliknya.

Dengan pengoptimalan peran media massa, maka akan meningkatkan dampak yang dihasilkan baik secara kognitif, efektif dan konitif. Sehingga meningkatkan kesadaran masyarakat terhadap pentingnya vaksinasi covid-19 sebagai upaya sentral dalam penekanan penyebaran virus covid-19 dan segera melakukan vaksinasi Covid-19 sesuai yang dihimbau oleh pemeritah. Kemudian, informasi-informasi yang tersedia di website resmi Covid-19 menampilkan informasi mengenai vaksin covid-19, agar informasi-informasi tersebut bisa dibaca oleh masyarakat Kabupaten Sidoarjo. 


\section{Referensi}

Akbar, M.Yudi Ali, Rizqi Maulida, dan Izzatul Fitriah. "Hubungan Relijiusitas dengan Self Awareness Mahasiswa Program Studi Bimbingan Penyuluhan Islam (Konseling) UAI." Jurnal Al-Azhar Indonesia Seri Humaniora 4, no. 4 (September, 2018): 265-270. DOI: http://dx.doi.org/10.36722/sh.v $4 \mathrm{i} 4.304$

Akbar, Syarifuddin. "Media Komunikasi Dalam Mendukung Penyebarluasan Informasi Penanggulangan Pandemi Covid-19." Jurnal Kominfo 2, no. 1 (Juni 2021): 73-82. https://jurnal.kominfo.go.id/index.p $\mathrm{hp} / \mathrm{mkm} /$ article/view/4099

Astuti, Runik Sri. "Sidoarjo Kerahkan Tim Percepatan Vaksinasi Covid-19 hingga Penjemputan Isoman." Kompas.id, 24 Agustus, 2021. https://www.kompas.id/baca/nusant ara/2021/08/18/sidoarjo-kerahkantim-percepatan-vaksinasi-covid-19hingga-penjemputan-isoman/.

Baihaqi, Amir. "Pj. Bupati Sidoarjo: Penanganan COVID-19 Tentukan Keberhasilan Pembangunan." DetikNews, 6 Oktober, 2020. https://news.detik.com/berita-jawatimur/d-5202626/pj-bupati-sidoarjopenanganan-covid-19-tentukankeberhasilan-pembangunan.

Bakry, Umar Suryadi. Metode Penelitian Hubungan Internasional. Yogyakarta: Pustaka Pelajar, 2016.

BUMN Farmasi Biofarma. "Vaksin." Diakses 18 November, 2021, https://www .biofarma.co .id/id/r esearcher/detail/vaksin.

Cherry, Kendra. "Self-Awareness Development and Types." Verrywell. Diakses 14 Juli, 2020. https://www.verywellmind.com/wha t-is-self-awareness-2795023
Choiriyati, Sri. "Peran Media Massa dalam Membentuk Opini Publik." Jurnal Universitas Muhammadiyah Lampung 2, no. 2 (2015): (21-27). http://journal.uml.ac.id/PF/article/vi ew/143/126

Creswell, John W. Research Design: Pendekatan Metode Kuantitatif, Kualitatif dan Campuran. Ed 4. Yogyakarta: Pustaka Pelajar, 2016.

Debora, Yantina. "Lokasi Vaksin Corona Sidoarjo 26-30 Agustus 2021 Dosis 1, 2 dan 3." Tirto.id, 26 Agustus, 2021. https://tirto.id/lokasi-vaksincorona-sidoarjo-26-30-agustus2021-dosis-1-2-dan-3-giY1

Fabriar, Silvia Riskha. "Etika Media Massa." An-Nida; Jurnal Komunikasi Islam 6, no. 1 (Januari 2014): $70-84$ DOI: https://doi.org/10.34001/an.v6i 1.174

Herdianto, EnggarFuri. "Vaksin dan Pandemi Covid-19." Blog-Latest News FPSCS. Diakses 28 Desember, 2020.

https://fpscs.uii.ac.id/blog/2020/12/2 8/vaksin-dan-pandemi-covid-19/

Hilmawan, Rachmanda Bayu. "Hubungan Self Awareness Dengan Deindividuasi Pada Remaja Pengguna Digital Piracy." Skripsi, Universitas Islam Negeri Sunan Ampel Surabaya, 2018.

Kabupaten Sidoarjo. "Mitra Media." Diakses 24 Agustus, 2021. http://www.sidoarjokab.go.id/mitramedia

Kementrian Komunikasi dan Informasi RI. "Pemerintah Terus Dorong Pengendalian Laju Penyebaran Covid-19." Diakses 20 Agustus, 2021.

https://www.kominfo.go.id/content/ detail/36050/pemerintah-terusdorong-pengendalian-lajupenyebaran-covid-19/0/berita 
Komariah, Kokom \&Subekti, Priyo. "Penggunaan Media Massa Sebagai Agen Sosialisasi Dinas Kesehatan Kabupaten Tasikmalaya dalam Meningkatkan Kesadaran Masyarakat akan Pentingnya Imunisasi." Jurnal Ilmiah Program Studi Hubungan Masyarakat 1, no.1 (Agustus 2016): 12-21. DOI : https://doi.org/10.24198/prh.v1i1.9 502

Nye, Joseph S. "Public Diplomacy and Soft Power." The Annals of The American Academy 616 no. 1 (March 2008): 94-109. https://doi.org/10.1177/0002716207 311699

Pusat Informasi dan Komunikasi COVID19 Kabupaten Sidoarjo. "Angka Kejadian." Diakses 20 Agustus, 2021, https://covid19.sidoarjokab.go.id/W elcome\#angka.

Rokom. "Vaksin COVID-19 Merek Sinovac, Astra Zeneca, Pfizer, dan Novavax Tidak Dapat Dipergunakan untukVaksinasi Gotong Royong." Sehat Negeriku, 15 Juni, 2021. https://sehatnegeriku.kemkes.go.id/b aca/beritautama/20210615/1837903/ vaksincovid-19-merek-sinovacastrazeneca-pfizer-dan-novavaxtidak-dapat-dipergunakan-untukvaksinasi-gotong-royong/

Sabrina, Isa dan Jerry Indrawan. "Mengembangkan Kesadaran Diri (Self-Awareness) Masyarakat untuk MenghadapiAncaman Nontradisional: Studi Kasus Covid-19." Jurnal Kajian Lemhannas RI. 8, no. 2 (September 2020): 144-163. http://jurnal.lemhannas.go.id/index. php/jkl/article/view/99

Sugiyono. Metode Penelitian Kebijakan: Pendekatan Kuantitatif, Kualitatif, Kombinasi, $R \& D$ dan Penelitihan
Evaluasi. Bandung: CV. Alfabeta, 2017.

World Health Organization. "Coronavirus Disease (COVID-19): Vaccines." Diakses 24 Agustus, 2021. https://www.who.int/news-room/qa-detail/coronavirus-disease-(covid19)-vaccines. 